\title{
Organic and Trace Element Geochemistry of the Ameki Formation, South Eastern Nigeria: Implications and Hydrocarbon Generating Potential
}

\author{
Nzekwe, I. E. And Okoro, A. U. \\ Department of Geological Sciences, Nnamdi Azikiwe University, P.M.B 5025, Awka.
}

\begin{abstract}
:
The source generative potential of the Ameki Formation in Umuahia, area, southeast Nigeria, was investigated using organic geochemical and trace element geochemistry. Results obtained from organic geochemical analysis reveal an overall organic richness with total organic carbon contents ranging from 0.28 to $4.35 w t \% T O C$. The amount of generated hydrocarbon through cracking of the kerogen, $S_{2}$, recorded from the rock-eval pyrolysis ranges from 0.14 to $3.57 \mathrm{wt} \%$. This suggests low hydrocarbon generative potential. The organic matter consists predominantly of inert Type IV kerogen and insignificant gas prone Type III kerogen. Tmax values range from 391 to $423^{\circ} \mathrm{C}$ with an average of $413^{\circ} \mathrm{C}$, which indicates source rock immaturity and no oil generative potential. Trace element geochemistry indicates that ratios of redox proxies $\mathrm{Ni} / \mathrm{Co}$ and $\mathrm{V} / \mathrm{Cr}$ varies from $1.35-6.80$ and $0.74-2.21$ respectively. This may suggest that organic matter deposition in the formation took place under oxic conditions. This study therefore shows that the Ameki Formation contains mainly Type IV kerogen with no hydrocarbon generating potential; is immature and was deposited under oxic conditions.
\end{abstract}

Keywords: Ameki Formation, kerogen, paleo-redox conditions, rock eval pyrolysis, trace elements.

\section{Introduction}

Petroleum source rocks are primary components of the petroleum system concept (Magoon and Dow, 1994). They constitute the precursors of petroleum which, under favourable condition, may subsequently migrate to reservoirs and traps and be sealed to form producible hydrocarbon accumulations. For producible hydrocarbon accumulation to occur, several essential geological elements and processes must be present at specific time and space (Magoon and Dow, 1994; Margoon et al., 1999). A mature source rock that is capable of generating and expelling hydrocarbon, migration pathway (faults and permeable strata) into reservoir, traps and impermeable sealing rocks must be present. These elements and processes create a petroleum system which is a favorable petroleum exploration target within a sedimentary basin.

In petroleum exploration, organic and trace element geochemistry has proved to be one of the useful tools in evaluating the hydrocarbon potentials and redox depositional environments of sedimentary basins (Ekweozor et al., 1980; Doust and Omatsola, 1990; Harris et al., 2004). The preservation of organic matter necessary for generating petroleum in source rocks is enhanced when deposition occurs within an oxygendeficient (anoxic) environment (Calvert and Pederson, 1993). This environment can be identified by analyzing relevant redox-sensitive trace elements contained in the rocks (Algeo and Maynard, 2004). Redox-sensitive trace elements commonly exhibit enrichment in laminated organic-rich facies, especially those deposited under euxinic conditions, and conversely, little if any enrichment in bioturbated, organic-poor facies (Calvert and Pederson, 1993; Algeo and Maynard, 2004). An understanding of the paleo-redox conditions of deposition is of paramount importance to petroleum exploration since the most favourable source rocks are deposited under reducing conditions.

The Nigerian Eocene sediments are well dated marine deposits and unfossiliferous beds of terrestrial origin, referred by inference based on stratigraphic positions, to the Eocene (Reyment, 1965). These Eocene rocks that outcropped in South-eastern Nigeria have been classified under the Ameki Group and consists of the Ameki Formation, Nanka Formation and Nsugbe Formation. The Ameki Formation (Eocene) is one of the lithostratigraphic units of the Tertiary Niger Delta (Short and Stauble, 1967). It is the outcropping equivalent of the subsurface Lower Agbada Formation which according to Short and Stauble (1967) and Frank and Cordry (1967) have been identified along with the Akata Formation to be the major source rocks of petroleum in the Niger Delta.

This research aims at integrating organic geochemistry and trace element studies so as to evaluate the hydrocarbon generating potential of the shales/mudrocks of the Ameki Formation by assessing the provenance and type of sedimentary organic matter, thermal maturity and depositional conditions. 


\section{Geologic Setting}

The initiation of the southern Nigerian sedimentary basins followed the breakup of the South American and African continents in the Early Cretaceous (Murat, 1972; Burke, 1976). Various lines of geomorphologic, structural, stratigraphic and paleontological evidences have been presented to support a rift model (Reyment, 1969; Burke et al., 1971, 1972; Benkhelil, 1989) for the opening of these basins. The stratigraphic history of southern Nigerian sedimentary basins is characterised by three sedimentary cycles (Short and Stauble, 1967; Murat, 1972) comprising: (i) the Abakaliki - Benue phase (Aptian - Santonian), (ii) Anambra - Benin phase (Campanian - Mid Eocene) and (iii) the Niger Delta phase (Paleocene - Recent) (Table 2). The over 3000 meters thickness of rock comprising the Asu River Group, the Eze-Aku and the Awgu Formations, were deposited during the first cycle in the southern Benue Trough and the Calabar Flank (Whiteman, 1982). The second sedimentary cycle started after the Santonian folding and uplift of the Abakaliki Anticlinorium and dislocation of the depocenters into the Anambra Basin and Afikpo Sub-basin (Murat, 1972). The resulting succession comprises the Nkporo Group, the Mamu Formation, the Ajali Sandstone and the Nsukka Formation. The third sedimentary cycle commenced in the Paleocene as the Anambra Basin got filled up and the depocenter shifted further south into the petroliferous Niger Delta Basin which has continued to prograde southward.

The Ameki Formation (Eocene) was deposited during the third sedimentary phase (Short and Stauble, 1967; Murat, 1972). Short and Stauble (1967) showed that the Ameki Formation is the surface or updip equivalent of the subsurface Agbada Formation exposed along the northern perimeter of the Niger Delta. Its lithologic units fall into two general groups: an upper grey-green sandstone and sandy clay and a lower unit with fine to coarse sandstone and intercalations of calcareous shales and thin shelly limestone (Reyment, 1965; Whiteman, 1982; Arua, 1986). The formation displays rapid lateral facies changes and may locally show shale developments or inclusions of white and mottled claystone and sandstone (Reyment, 1965).

The underlying Imo Formation (Paleocene) and overlying Ogwashi-Asaba Formation (Oligocene) were also deposited during the third sedimentary phase (Table 2) and represents the updip equivalents of the Akata Formation and Upper Agbada Formation respectively.

Table 2: Regional Stratigraphic Succession of South-eastern Nigeria (modified from Reyment, 1965; Murat,

\begin{tabular}{|c|c|c|c|}
\hline \multicolumn{4}{|c|}{ 1972) } \\
\hline Age & Formation & Lithologic Descriptions & Sedimentary Cycle \\
\hline Pliocene & Benin Formation & Continental sands & \multirow{4}{*}{$\begin{array}{l}\text { Niger Delta Basin } \\
\left(3^{\text {rd }} \text { Sedimentary Cycle }\right)\end{array}$} \\
\hline Pleistocene & Ogwashi-Asaba Formation & $\begin{array}{l}\text { Lignite, sandstones, shales } \\
\text { and clays }\end{array}$ & \\
\hline Eocene & Ameki Formation & Sandstones, clays and shales. & \\
\hline Paleocene & Imo Formation & $\begin{array}{l}\text { Sandstones, clays, limestones } \\
\text { and marl }\end{array}$ & \\
\hline \multirow[t]{3}{*}{ Maastrichtian } & Nsukka Formation & $\begin{array}{l}\text { Sandstones, clays, coals, } \\
\text { shales and limestones }\end{array}$ & \multirow[b]{4}{*}{$\begin{array}{l}\text { Anambra - Afikpo Basin } \\
\left(2^{\text {nd }} \text { Sedimentary Cycle }\right)\end{array}$} \\
\hline & Ajali Formation & Sandstones, claystones & \\
\hline & Mamu Formation & Sandstones, clays and coals & \\
\hline Campanian & $\begin{array}{l}\text { Nkporo Formation \& lateral equivalents- } \\
\text { Enugu Formation, } \\
\text { Afikpo Sandstone, Owelli Sandstone and } \\
\text { Otobi Sandstone }\end{array}$ & $\begin{array}{l}\text { Sandstones, clays, shales, } \\
\text { ironstones and siltstones. }\end{array}$ & \\
\hline Santonian & Non-deposition & Non-deposition & \multirow[t]{2}{*}{ Non-deposition } \\
\hline Coniacian & Awgu Shale & $\begin{array}{l}\text { Sandstones, limestones, clays, } \\
\text { coals and siltstones. }\end{array}$ & \\
\hline Turanian & Ezeaku Group & $\begin{array}{l}\begin{array}{l}\text { Shales, limestones and } \\
\text { sandstones }\end{array}\end{array}$ & \multirow{3}{*}{$\begin{array}{l}\text { Abakaliki - Benue Basin } \\
\left(1^{\text {st }} \text { Sedimentary Cycle }\right)\end{array}$} \\
\hline Cenomanian & Odukpani Formation & $\begin{array}{l}\text { Sandstones, limestones and } \\
\text { shales }\end{array}$ & \\
\hline Albian & Asu River Group & $\begin{array}{l}\text { Shales, limestones and } \\
\text { sandstones. }\end{array}$ & \\
\hline Precambrian & \multicolumn{3}{|l|}{ Crystalline Basement Complex } \\
\hline
\end{tabular}

The age of the Ameki Formation has been interpreted as early - middle Eocene (Reyment, 1965; Berggren, 1960; Adegoke, 1969). The depositional environments have been interpreted as estuarine to open marine based on faunal contents and lithofacies (Adegoke, 1969; Arua, 1986). Adegoke (1969), however, indicated that the fish were probably washed into the Ameki Sea from inland waters, and preferred an open marine depositional environment. Nwajide (1979) and Arua (1986) suggested environments that ranged from nearshore (barrier ridge-lagoonal complex) to intertidal and subtidal zones of shelf environments, whereas Fayose and Ola (1990) suggested that the sediments were deposited in marine waters between the depths of $10 \mathrm{~m}$ and $100 \mathrm{~m}$ 
It has been established that the Agbada Formation which is the subsurface equivalent of the Ameki Formation has generated substantial volume of hydrocarbon in the down-dip Niger Delta. Nwachukwu and Chukwura (1986) noted that the Agbada Formation has intervals that contain sufficient organic carbon contents that are mature to generate hydrocarbon. Evamy et al. (1978) also proposed, based on organic matter content and type, that both the marine shale of the Akata Formation and shales interbedded with paralic sandstones in the Agbada Formation are the source rocks of the Niger Delta hydrocarbon. The purpose of this study is to assess the generative potential of the organic matter in the shales of the Ameki Formation, which is the outcropping equivalent Agbada Formation, as well as the paleo-oceanographic conditions under which the shales were deposited.

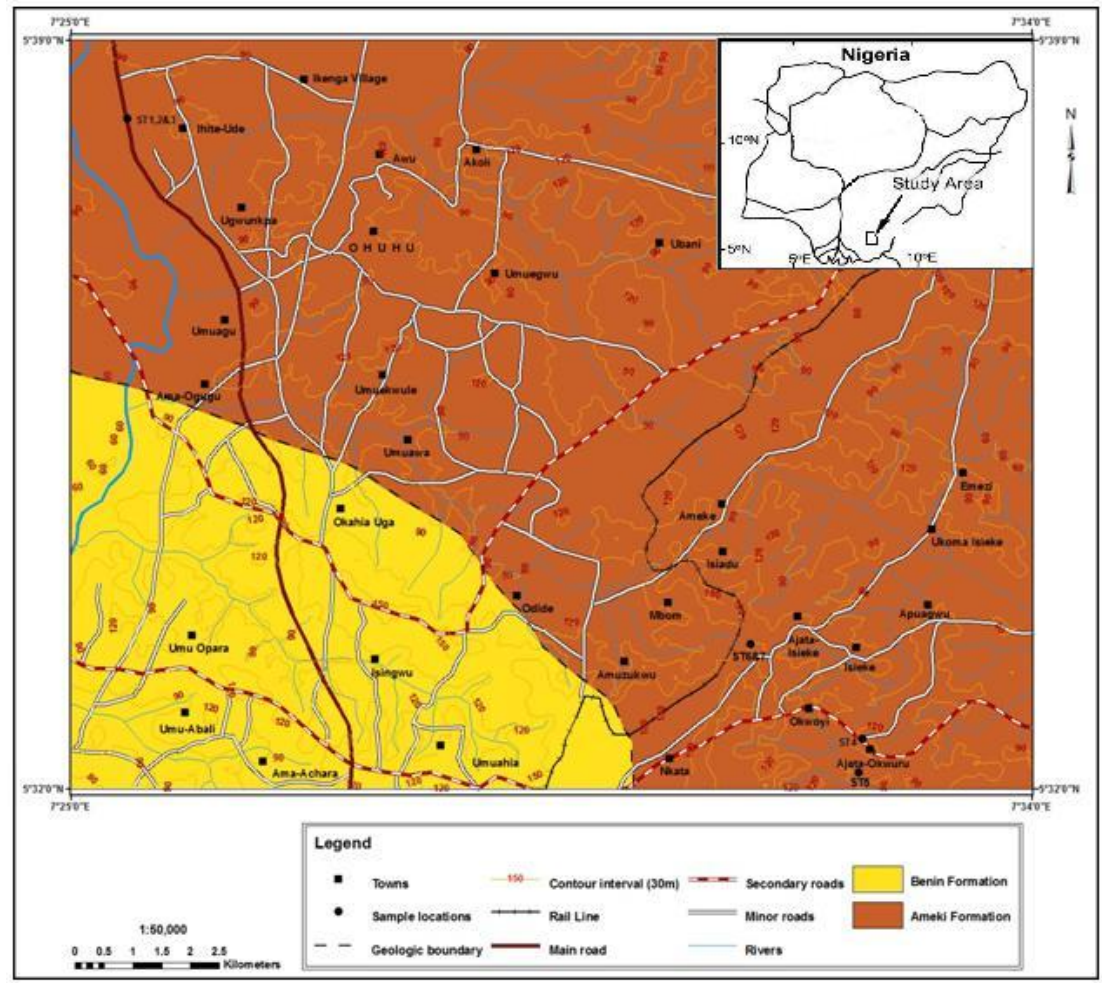

Fig 1: Geologic map of the study area showing sample locations.

\section{Sample Collection}

\section{Materials And Method}

Seven (7) fresh samples were collected at different locations from four outcrop sections of the Ameki Formation. The outcrop locations include; Ofueme, Ajata Isieke and Isiadu near Ameke village, the type locality of the Ameki Formation (Fig.1). Sample coordinates and elevations were obtained using Global Positioning System (GPS) device. Samples were packaged in black nylon bags, labelled and sent to Gettamme Geochemical Laboratory, Port Harcourt for analysis.

\section{Lithologic Description}

Studied outcrops comprise dominantly mudrocks which become silty towards the south at higher elevations. The outcrop exposed at Ofueme, along the Enugu - Port Harcourt Express Way comprises dark grey gypsiferous mudrocks, rich in amber (fossil resin). The rocks are poorly laminated and bioturbated with thin lignite bands present. At other locations, the shales/mudrocks become silty especially towards Ajata Isieke and Isiadu where exposures are at higher elevation. In these areas, the shales become bluish, laminated and highly fossiliferous with remains of bivalve shells present. Towards Bende, there is a lateral facies change into calcerous pebbly sandstone (Bende Sandstone) exposed along the Inyang River. The white, coarse sandstone is highly fossiliferous with remains of bivalve and echinoid shells which suggest deposition in marine environment.

\section{Total Organic Carbon Analysis}

200mg of pre-cleaned samples were crushed and accurately weighed into clean LECO Crucibles. The rock samples were then de-mineralized by hot $10 \% \mathrm{HCL}$ and afterwards washed repeatedly with distilled water. 
After drying at $60^{\circ} \mathrm{C}$, the crucibles were automatically introduced into the furnace of LECO CS 125 Carbon analyzer for combustion and measurement of the organic carbon contents.

\section{Rock Eval Pyrolysis}

The Rock eval pyrolysis analytical process involves transfer of sample into a furnace where they are heated initially at $300^{\circ} \mathrm{C}$ for three minutes in an atmosphere of helium to release the free hydrocarbons $\left(S_{1}\right)$. Pyrolysis of the bound hydrocarbons to give the $S_{2}$ peak follows immediately as the oven temperature ramp up rapidly to $550^{\circ} \mathrm{C}$ at the rate of $25^{\circ} \mathrm{C} / \mathrm{min}$. Both the $S_{1}$ and $S_{2}$ hydrocarbon peaks are measured using a flame ionization detector (FID). A splitting arrangement permitted the measurement of the $S_{3}$ peak (carbon dioxide) by means of a thermal conductivity detector (TCD). The instrument automatically records the temperature corresponding to the maximum of the $S_{2}$ peak i.e Tmax. An in-built computer processes the raw data to generate the values corresponding to the respective Rock-Eval indices.

\begin{tabular}{|c|c|c|c|c|}
\hline $\begin{array}{l}\text { Thickness } \\
\text { (m) }\end{array}$ & Lithology & $\begin{array}{c}\text { Sample } \\
\text { No }\end{array}$ & GPS & Description \\
\hline \multirow{2}{*}{153} & $\backslash 1 / \backslash 1 /$ & \multirow{3}{*}{ Sample vii } & \multirow{3}{*}{$\begin{array}{l}\text { N 5' 33" } \\
\text { E7' 31" }\end{array}$} & \multirow{3}{*}{$\begin{array}{l}\text { Overburden } \\
\text { Well laminated highly silty bioturbated brown coloured shales }\end{array}$} \\
\hline & & & & \\
\hline \multirow[t]{3}{*}{152} & + & & & \\
\hline & 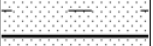 & \multirow[t]{2}{*}{ Sample vi } & \multirow{2}{*}{$\begin{array}{l}\text { N 5' } 33^{\prime \prime} \\
\text { E7' } 31^{\prime \prime}\end{array}$} & \multirow[t]{2}{*}{ Well laminated highly silty bioturbated brown coloured shales } \\
\hline & - & & & \\
\hline \multirow{4}{*}{102} & $-\ldots$ & \multirow{5}{*}{ Sample iv } & \multirow{4}{*}{$\begin{array}{l}\text { N5' 32" } \\
\text { E7' 32" }\end{array}$} & \multirow{5}{*}{ Well laminated highly silty bluish grey shales } \\
\hline & - & & & \\
\hline & $=\quad$ 二 & & & \\
\hline & $-\quad-$ & & & \\
\hline \multirow{2}{*}{88} & $-\quad-\quad-$ & & & \\
\hline & $- 0 \longdiv { - }$ & \multirow[t]{2}{*}{ Sample v } & N5' 32" & Dark brown coloured poorly laminated shales/mudstone. \\
\hline \multirow{2}{*}{82} & $-\mathrm{OH}$ & & & \\
\hline & $.00-\overline{0}$ & Sample iii & N5'38" & Poorly laminated grey coloured gypsiferous shales/mudstone \\
\hline 81 & $.00-\overline{0}$ & Sample ii & N5' $38^{\prime \prime}$ & Poorly laminated grey coloured gypsiferous shales/mudstone \\
\hline 80 & $0-0-$ & Sample i & E7' $25^{\prime \prime}$ & $\begin{array}{l}\text { Poorly laminated grey coloured gypsiferous shales/mudstone } \\
\text { rich in amber and phosphate noodles }\end{array}$ \\
\hline
\end{tabular}

Fig. 2: Lithologic Section of Ameki Formation.

\section{Trace Element Geochemistry}

$1 \mathrm{~g}$ of air dried sample is transferred into a $250 \mathrm{ml}$ conical flask and a mixture of perchloric acid, nitric acid and sulphuric acid in the ratio 1:2:2 were added. The mixture is placed on a hot plate for about 15-20 minutes and properly digested until a white fume is observed. After cooling, $20 \mathrm{ml}$ distilled water is added to bring the metal into solution. The solution is then filtered through Whatman 2 filter paper into a $100 \mathrm{ml}$ volumetric flask, then transferred into a 100ml plastic bottle for Atomic Absorption Spectrometer analysis.

\section{Results And Discussions}

Table 2: TOC and Rock-Eval Pyrolysis Result

\begin{tabular}{|c|c|c|c|c|c|c|c|c|c|c|c|c|c|}
\hline \multirow[t]{2}{*}{$\mathbf{S} / \mathbf{N}$} & \multirow{2}{*}{$\begin{array}{l}\text { Client } \\
\text { ID }\end{array}$} & \multirow{2}{*}{$\begin{array}{l}\text { Sample } \\
\text { Elevation } \\
\text { (m) }\end{array}$} & \multirow{2}{*}{$\begin{array}{l}\text { Sample } \\
\text { Type }\end{array}$} & \multirow{2}{*}{$\begin{array}{l}\text { Leco } \\
\text { TOC }\end{array}$} & \multicolumn{3}{|c|}{$\mathbf{R E}$} & \multirow{2}{*}{$\begin{array}{l}\text { Tmax } \\
\left({ }^{\circ} \mathbf{C}\right)\end{array}$} & \multirow[t]{2}{*}{ HI } & \multirow[t]{2}{*}{ OI } & \multirow{2}{*}{$\begin{array}{l}\text { S2/ } \\
\text { S3 }\end{array}$} & \multirow{2}{*}{$\begin{array}{l}\text { S1/ } \\
\text { TO } \\
\text { C } \\
\end{array}$} & \multirow[t]{2}{*}{ PI } \\
\hline & & & & & S1 & $\mathbf{S 2}$ & S3 & & & & & & \\
\hline 1 & SA-I & 79.9 & Rock & 4.35 & 0.15 & 3.57 & 2.59 & 419 & 82 & 60 & 1.4 & 3 & 0.04 \\
\hline 2 & SA-II & 80.2 & Rock & 3.22 & 0.08 & 0.72 & 3.13 & 415 & 22 & 97 & 0.2 & 2 & 0.10 \\
\hline 3 & SA-III & 82.4 & Rock & 2.15 & 0.15 & 0.87 & 1.00 & 407 & 40 & 47 & 0.9 & 7 & 0.15 \\
\hline 4 & SA-V & 87.8 & Rock & 0.28 & 0.03 & 0.17 & 0.43 & 423 & 61 & 155 & 0.4 & 11 & 0.15 \\
\hline 5 & SA-IV & 101.9 & Rock & 1.64 & 0.06 & 0.94 & 1.15 & 417 & 57 & 70 & 0.8 & 4 & 0.06 \\
\hline 6 & SA-VI & 151.9 & Rock & 0.69 & 0.04 & 0.15 & 1.68 & 417 & 22 & 243 & 0.1 & 6 & 0.21 \\
\hline 7 & SA-VII & 152.5 & Rock & 0.69 & 0.03 & 0.14 & 1.20 & 391 & 20 & 173 & 0.1 & 4 & 0.18 \\
\hline
\end{tabular}

\section{Organic Richness}

The TOC values of the analysed samples of the Ameki Formation range from 0.28 to $4.35 \%$ wt with samples VI and VII recording values slightly higher than the minimum concentration for petroleum generation (Table 2). The lowest organic carbon concentration which falls below the minimum concentration of $0.5 \%$ wt 
threshold for hydrocarbon generation was recorded in sample IV and suggests insufficient organic matter available for petroleum generation. The results also show a systematic increase in organic richness with depth. Samples obtained at shallower depths recorded lower TOC concentrations than those from deeper depths. This suggests increasing oxic conditions towards the top of the Ameki Formation.

\section{Organic Quality}

The results obtained from the rock-eval pyrolysis of revealed that the amount of free hydrocarbon $\left(\mathrm{S}_{1}\right)$, and the generated hydrocarbons $\left(\mathrm{S}_{2}\right)$ through thermal cracking of non-volatiles are relatively low, with the highest $S_{2}$ value recorded in SA-I (Table 2). $S_{1}$ values range from 0.03 to $0.15 \mathrm{mg} \mathrm{HC} / \mathrm{gTOC}$ which suggests negligible amount of free hydrocarbon at present maturity. Generally, $\mathrm{S}_{1}$ values greater than $1 \mathrm{mg} \mathrm{HC} / \mathrm{g}$ TOC in any organic rock is indicative of hydrocarbon shows (Okeke et al., 2013). This is clearly not the case for the Ameki Formation. $\mathrm{S}_{2}$ values, ranging from 0.14 to $3.57 \mathrm{mg} \mathrm{HC} / \mathrm{g}$ TOC. which is indicative of the remaining potential of kerogen in the source rock to generate petroleum at higher tempratures is relatively low.

The low $\mathrm{S}_{2}$ values compliment the extremely low TOC values recorded in most samples. However, samples SA-I, SA-II and SA-III display considerably higher $\mathrm{S}_{2}$ value. SA-I, with $\mathrm{S}_{2}$ value of $3.57 \mathrm{mg} \mathrm{HC} / \mathrm{g}$ TOC, shows the highest hydrocarbon generation prospect.

\section{Kerogen Type}

The analysed samples of the Ameki Formation are characterized by low hydrogen index values ranging from $20-82 \mathrm{mg} \mathrm{HC} / \mathrm{g}$ TOC (Table 2) and very high oxygen index values ranging from 47-243mg HC/g TOC This is indicative of highly oxidized organic matter (Type IV) kerogen with possible exception for Sample SA-I (Fig. 3 and 6). Plot of Hydrogen Index (HI) against Oxygen Index (OI) on the Van Krevelen diagram (Van Krevelen, 1984; Tissot and Welte, 1984), reveals that all but one sample fall within Type IV kerogen (Fig. 3). This suggests oxidized organic matter with no oil generating potential. Sample SA-I with the highest Hydrogen Index $(\mathrm{HI}=82 \mathrm{mg} \mathrm{HC} / \mathrm{g}$ TOC) falls within Type III kerogen and suggests terrestrially derived, gas prone source rock.

\section{Thermal Maturity}

Tmax values of the Ameki Formation ranges from $391-423^{\circ} \mathrm{C}$ (Table 2). This suggests that the shales are still within the immature stage of thermal maturation as they fall below the required temperature for catagenesis (Fig. 5). Peters (1986) suggested that at Tmax $435^{\circ} \mathrm{C}$, rocks with HI above $300 \mathrm{mg} \mathrm{HC} / \mathrm{g}$ TOC will produce oil; those with HI between 300 and 150 will produce oil and gas; those with HI between 150 and 50 will produce only gas; and those with HI less than 50 are inert. Plot of hydrogen index against Tmax (Fig. 4 and 5) confirm the immature status of the Ameki shales and mudrocks analysed with all samples plotting within the immature range.

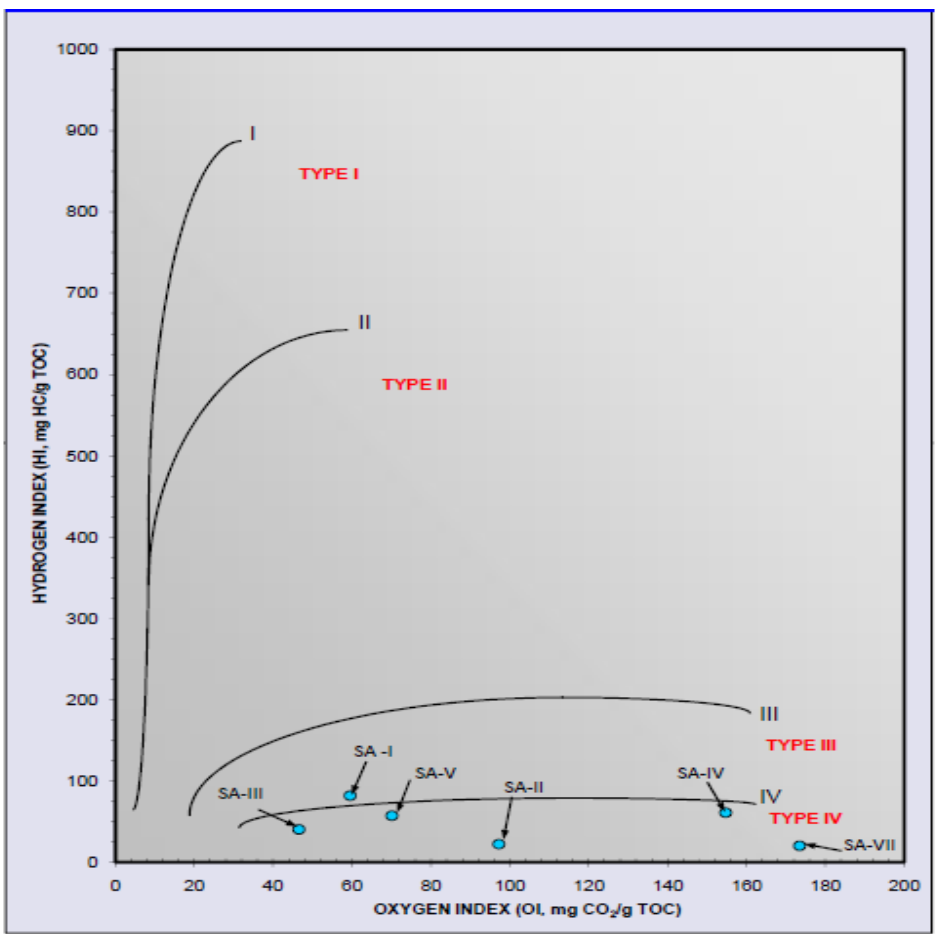

Fig. 3: Plot of Hydrogen Index against Oxygen Index of the samples on the Van Krevelen diagram 


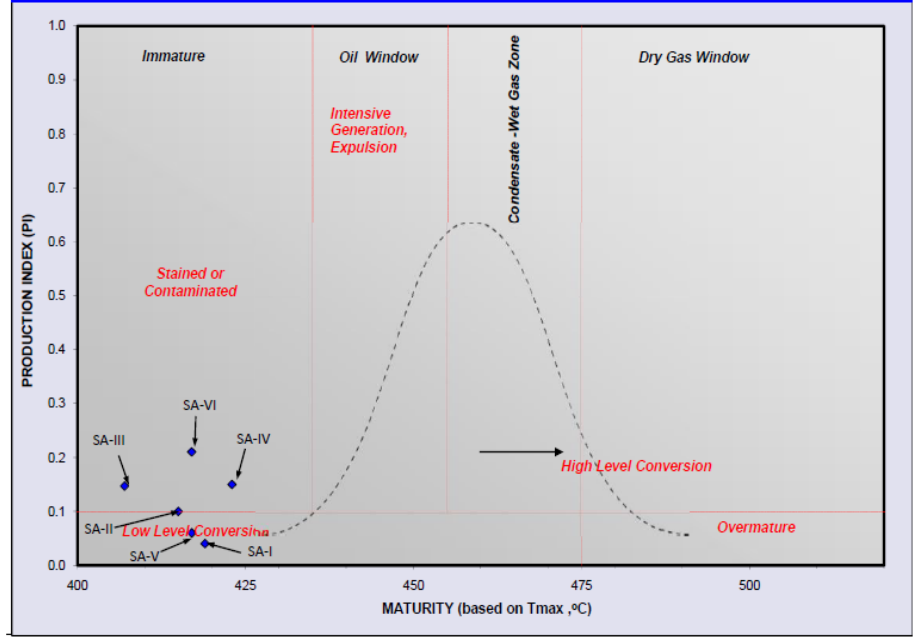

Fig. 4: Plot of Production Index against Tmax indicating immature stage of samples

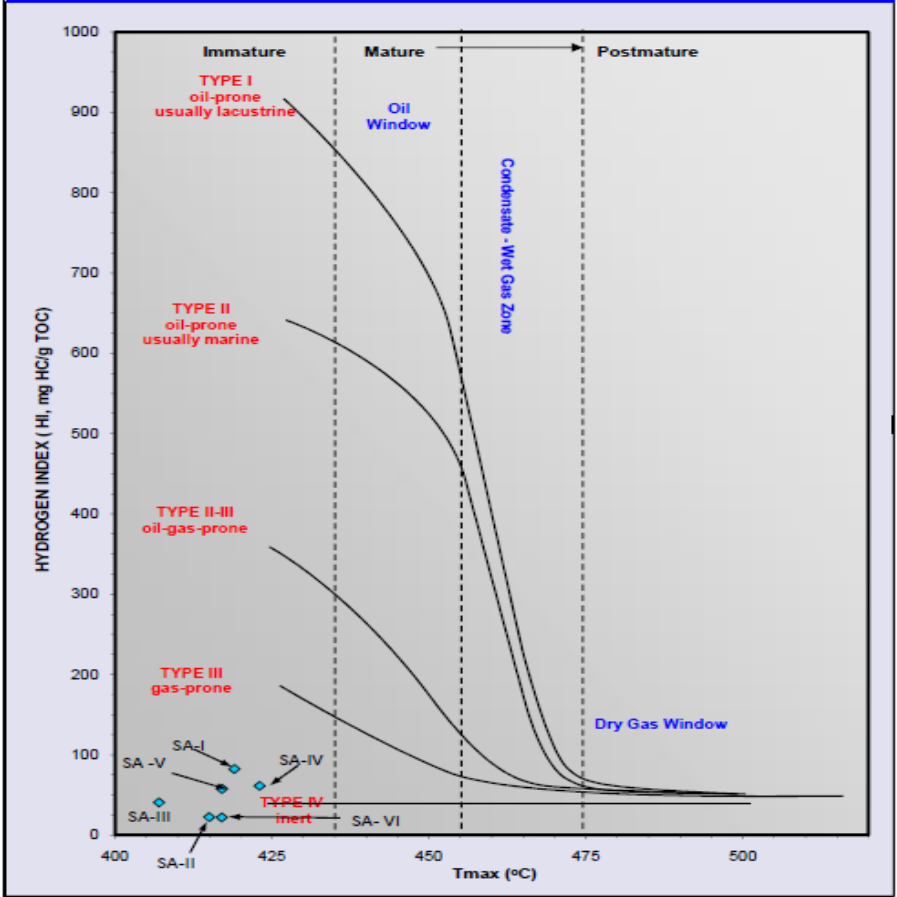

Fig. 5: Plot of Hydrogen Index against Tmax.

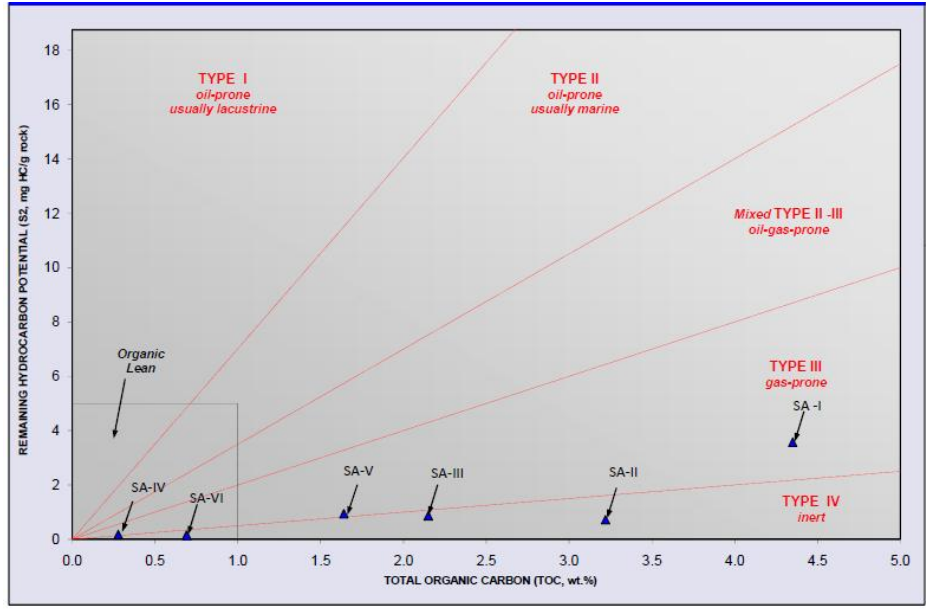

Fig. 6 Plot of $S_{2}$ against TOC 


\section{Redox sensitive trace element concentrations}

Trace element concentration has been used as an indicator of paleo-redox conditions in the study of source rocks (vine and Tourtelot 1970; Calvert and Pederson, 1993; Esmat and Mohammed 2015). High enrichment of trace elements especially in black shales are related to anoxic or euxinic environments (vine and Tourtelot 1970; Algeo and Maynard 2004). The result of redox - sensitive trace element composition of the Ameki Formation is shown in Table 3. Nickel (Ni), cobalt (Co), chromium (Cr), molybdenum (Mo), vanadium (V) and copper $(\mathrm{Cu})$ are generally low in the Formation with Vanadium showing the highest overall concentration ranging from 2.00-3.25ppm (Table 3). Trace element concentrations are generally depleted compared to average black shale values (Vine and Tourtelot, 1970). This suggests deposition under oxic conditions.

Table 3: Redox sensitive trace elements concentrations and redox proxies (All concentrations are in ppm)

\begin{tabular}{|l|l|l|l|l|l|l|l|l|}
\hline S/N & Cr & Co & $\mathbf{C u}$ & $\mathbf{V}$ & $\mathbf{N i}$ & $\mathbf{M o}$ & $\mathbf{V / C r}$ & $\mathbf{N i / C o}$ \\
\hline 1 & 2.127 & 0.101 & 0.061 & 3.015 & 0.381 & 1.254 & 1.420 & 3.770 \\
2 & 2.816 & 0.034 & 0.068 & 3.031 & 0.156 & 0.972 & 1.080 & 4.590 \\
3 & 2.162 & 0.271 & 0.082 & 2.340 & 0.397 & 1.586 & 1.080 & 1.460 \\
4 & 2.321 & 0.147 & 0.065 & 3.001 & 0.001 & 0.815 & 1.290 & 6.800 \\
5 & 1.472 & 0.048 & 0.063 & 3.251 & 0.111 & 1.430 & 2.210 & 2.310 \\
6 & 2.686 & 0.173 & 0.058 & 2.001 & 0.232 & 1.327 & 0.770 & 1.340 \\
7 & 2.009 & 0.230 & 0.066 & 2.104 & 0.001 & 1.021 & 1.050 & 4.350 \\
\hline Average Black & 100 & 10 & 70 & 150 & 50 & 10 & 3.22 & 6.80 \\
Shake (after Vine \\
and Tourtelot,
\end{tabular}

\section{Redox Proxies}

Molybdenum (Mo) has been suggested as an indicator of anoxic and more accurately, euxinic conditions with concentrations greater than $25 \mathrm{ppm}$ recorded in modern and ancient euxinic environments (Calvert and Pederson, 1993; Scott and Lyons, 2012). Mo concentration for the samples analysed range between $0.82-1.59 \mathrm{ppm}$. This suggests deposition under oxic conditions where Mo exists as soluble molybdate that adsorbs onto manganese oxide with slow precipitation (Algeo and Maynard, 2004).

Trace element indices including $\mathrm{Ni} / \mathrm{Co}$ and $\mathrm{V} / \mathrm{Cr}$ have been used to evaluate paleo-redox conditions (Hatch and Leventhal, 1992; Jones and Manning, 1994; Akinyemi et al., 2013). According to Jones and Manning (1994), $\mathrm{V} / \mathrm{Cr}$ ratios above 2 indicate anoxic conditions while values above 4 indicate euxinic conditions. Values below 2 suggest more oxidizing conditions. They also proposed Ni/Co ratios above 5 as indicative of dysoxic and anoxic conditions with values above 7 suggesting euxinic conditions. Ratios below 5 suggest oxic conditions.

Results obtained from the application of the above redox proxies reveal that most the Ameki shales and mudstones were deposited in essentially oxic paleo-environmental conditions (see Table 3). Ni/Co and $\mathrm{V} / \mathrm{Cr}$ ratios range between $1.35-6.80$ and $0.74-2.21$ respectively suggesting oxic to dysoxic conditions during deposition of the shales.

\section{Discussion Of Results}

Petroleum is a generative product of organic matter disseminated in sediments and therefore, the quantity of hydrocarbon generated directly correlates with organic matter concentration of the potential source rocks (Tissot and Welte 1984). The source rock characteristics of the Ameki Formation from this study reveals sufficient amount of organic matter necessary for hydrocarbon generation. However, the organic matter is dominantly composed of inertinite with no hydrocarbon generating potential at peak maturity.

Chiaghanam et al., 2014 carried out similar studies on the Ameki Group (Nanka Formation) and reported TOC values ranging from $2.40 \%$ wt to $4.50 \%$ wt. They also revealed source rock composed of type IV kerogen with Tmax ranging from $407-409^{\circ} \mathrm{C}$. These values are similar with the findings from this present study and suggest poor organic matter preservation as a result of sediment deposition under oxic settings.

Further downdip, studies reveal that the Agbada Formation is a contributing source rock for the Niger Delta oils (Evamy et al., 1978; Ekweozor and Okoye, 1980; Ejedawe and Okoh, 1981; Nwachukwu and Chukwurah, 1986; Akaegbobi, 2000). Asadu et al., 2015 recorded average TOC and Tmax values of 3.59\%wt and $432{ }^{\circ} \mathrm{C}$ respectively from their study on ditch cuttings from well X, penetrating the Agbada Formation. A mixture of Type II and III kerogen was also reported. Their result suggests high organic matter preservation probably as a result of rapid sedimentation and quick burial processes that took place in the Niger Delta. 


\section{Summary and Conclusions.}

Organic matter quality, quantity and depositional environment the Ameki Formation outcropping in the study area were assessed using organic geochemical and inorganic geochemical techniques to determine its hydrocarbon generative potential and redox condition of the depositional environment. The result of organic geochemical analysis shows that the TOC values range between $0.23-4.35 \mathrm{wt} \%$ with an average of $1.86 \mathrm{wt} \%$, which signifies good organic matter richness for the Ameki Formation. The TOC values also display a systematic increase with deeper burial depth. Rock eval pyrolysis revealed dominantly type IV kerogen with no oil generative potential except for SA-I which plots within the type III gas prone kerogen range Tmax values ranges from $391-423^{\circ} \mathrm{C}$ with an average of $413^{\circ} \mathrm{C}$ which indicates an overall thermal immaturity of the shales. Plots of production index (PI) against Tmax and hydrogen index (HI) against Tmax further confirms sample immaturity with respect to hydrocarbon generation.

Trace element concentrations and redox proxies revealed that enhanced oxygen levels persisted during the deposition of the Ameki Formation which is reflected in the generally high oxygen index values and kerogen type. Trace element concentrations were generally depleted compared to average black shale values (Vine and Tourtelot, 1970). Redox indices (especially $\mathrm{Ni} / \mathrm{Co}$ and $\mathrm{V} / \mathrm{Cr}$ ) also suggest oxidizing conditions during the sediment deposition.

It is therefore concluded that the Ameki Formation is dominantly composed of inert type IV kerogen without oil generative potential although gas prone type III kerogen appear to occur at deeper stratigraphic levels. The shales and mudstones did not attain the requisite maturity to generate hydrocarbon and are therefore immature. The Formation was deposited essentially under oxic paleo-environmental conditions.

\section{References}

[1]. Adegoke, O. S., 1969. Eocene stratigraphy of southern Nigeria. Colloquesur l' Eocene, III. Bureau de Recherches Geologiques et Minieres. 69, 22-48.

[2]. Akaegbobi, I. M. 2000. Application of geochemical techniques in kerogen classification and source rock evaluation of the Agbada Shale, Eastern Niger Delta. Journal of Mining and Geology. 36, 175-189.

[3]. Akinyemi, S. A., Adebayo, O. F., Ojo, O. A., Fadipe, O. A. and Gitari, W. M. 2013. Minerology and geochemical appraisal of paleo-redox indicators in Maastrichtian outcrop shales of Mamu Formation, Anambra Basin, Nigeria. Journal of natural Sciences Research. 3, No. 10.

[4]. Algeo, T. J. and Maynard, B. J., 2004. Trace-element behavior and redox facies in core shales of Upper Pennsylvanian Kansas-type Cyclothems. Chemical Geology. 206, 289-318.

[5]. Arua, I. 1986. Paleo-environment of Eocene deposits in the Afikpo Syncline, southern Nigeria. Journal of African Earth Sciences 5, 279-284.

[6]. Asadu, N., Lucas, F. A. and Ibe, K. A. 2015. Geochemical characterisation of Agbada Formation in well X, offshore, Niger Delta, Nigeria. International Journal of Science Inventions Today. 4(3), 247-262.

[7]. Benkhelil, J. 1989. The origin and evolution of the Cretaceous Benue Trough of Nigeria. Journal of Africa Earth Sciences. 8, 251282 .

[8]. Berggren, W. A. 1960. Paleocene biostratigraphy and planktonic foraminifera of Nigeria (West Africa). International Geologic Congress, Copenhagen, Report. 21(6), 41-55.

[9]. Burke, K.C. 1996. The African plate. South African Journal of Geology. 99, 341-402.

[10]. Burke, K. C, Dessauvagie, T. F. J. and Whiteman, A. J. 1971. The opening of the Gulf of Guinea and the geological history of the Benue depression and the Niger Delta. Nature. 233, 51-55.

[11]. Calvert, S. E. and Pedersen, T. F. 1993. Geochemistry of recent oxic and anoxic marine sediments: Implications for the geological record. Marine Geology. 113, 67-88.

[12]. Chiaghanam, O. I., Chiadikobi, K. C., Ikegwuonwu, O. N., Omoboriowo, A. O., Onyemesili, O. C. and Yikarebogha., Y. 2014. Source rock potential and thermal maturity of the Eocene Nanka Formation (Ameki Group) in Anambra Basin: An appraisal of Ogbunike reference locality, South Eastern Nigeria. Journal of Applied Geology and Geophysics. 2, 11-17.

[13]. Doust, H., and Omatsola, E. 1990. Niger Delta, in, Edwards, J. D., and Santogrossi, P. A., eds., Divergent/ passive margin Basins. AAPG Memoir 48: Tulsa, American Association of Petroleum Geologists, p. 239-248.

[14]. Ejedawe, J. E. and Okoh, S. U. 1981. Prediction of optimal depths of petroleum occurrences in the Niger Delta Basin. Journal of Mining and Geology. 18, 14-80.

[15]. Ekweozor, C. M. and Okoye, N. V. 1980. Petroleum source bed evaluation of the Tertiary Niger delta. American Association of Petroleum Geologists Bulletin. 64, 1251-1259.

[16]. Esmat, A. E. and Mohammed, M. G. 2015. Electrical, mineralogical, geochemical and provenance of Cretaceous Black shales, Red Sea Coast, Egypt. Egyptian Journal of Petroleum. 24, 397-404.

[17]. Evamy, B. D., Haremboure, J., Kamerling, P., Knaap, W. A., Molloy, F. A., and Rowlands, P. H. 1978. Hydrocarbon habitat of Tertiary Niger Delta. American Association of Petroleum Geologists Bulletin. 62, 277-298.

[18]. Fayose, E.A. and Ola, P.S., 1990. Radiolarian occurrences in the Ameki type section, eastern Nigeria. Journal of Mining and Geology 26, 75-80.

[19]. Frankl, E. J. and Cordry, E. A. 1967. The Niger delta oil province - recent developments onshore and offshore: 7th World Petroleum Cong., Mexico City, Proc., vol. 1B, 195-205.

[20]. Harris, N.B., Freeman, K.H., Pancost, R.D., White, T.S. and Mitchell, G.D., 2004. The character and origin of lacustrine source rocks in the Lower Cretaceous synrift section, Congo Basin, West Africa, AAPG Bulletin, v. 88, No. 8, pp. 1163 - 1184.

[21]. Hatch, J.R. and Leventhal, J.S., 1992. Relationship between Inferred redox potential of the depositional environment and geochemistry of the Upper Pennsylvanian (Missourian) Stark shale member of the Dennis Limestone, Wabaunsee County, Kansas, USA. Chemical Geology.99, 65- 82.

[22]. Jones, B. and Manning, D.A.C., 1994. Comparison of geochemical indices used for the interpretation of palaeoredox conditions in ancient mudstones. Chemical Geology. 111, $111-129$.

[23]. Magoon, L.B. and Dow, W.G., 1994. The Petroleum System - from source to trap: AAPG Memoir 60. pp. 3 - 24. 
[24]. Murat, R.C., 1972. Stratigraphy and paleogeography of the Cretaceous and lower Tertiary in southern Nigeria In: Dessauvagie, T. F.J. and Whiteman, A. (eds.). African Geology. UI Press: Ibadan, Nigeria. 635-641.

[25]. Nwachukwu, J. I and Chukwura, P. I. 1986. Organic matter of Agbada Formation, Niger Delta, Nigeria. American Association of Petroleum Geologist Bulletin. 70, 48-55.

[26]. Nwajide, C.S., 1979. A lithostratigraphic analysis of the Nanka Sands, southeastern Nigeria. Journal of Mining and Geology 16, 103-109.

[27]. Nwajide, C. S and Reijers, T. J. A. 1996. Anambra Basin excursion guide. In Reijers, T. J. A (eds). Selected Chapters on Geology. Shell Petroleum Company of Nigeria, Corporate Reprographic Services, Warri. 149-179.

[28]. Okeke, H. C., Orajaka, I. P., Okoro, A., Onuigbo, E. N. 2003. Biomarker evaluation of the oil generative potential of organic matter, in the Upper Maastrichtian strata, Anambra Basin, Southeastern Nigeria. Journal of Scientific Research. 2(1), 16-25.

[29]. Peters, K. E. 1986. Guidelines for evaluating petroleum source rocks using programmed pyrolysis. American Association of Petroleum Geologist Bulletin70, 318-329.

[30]. Reyment, R. A. 1965. Aspects of geology of Nigeria. University of Ibadan Press, Nigeria, 165p.

[31]. Reyment, R. A. 1969. Statistical analysis of some volcanologic data regarded as series of point events. Pure and Applied Geophysics. V. 74, p. 57-77.

[32]. Short, K. C., and Stauble, A. J. 1967. Outline of geology of Niger Delta. American Association of Petroleum Geologist Bulletin. 51, 761-779.

[33]. Tissot, B. G. and Welte, D. H. 1984. Petroleum formation and occurrence: A new approach to oil and gas exploration. Berlin, Springer-Verlag. 699.

[34]. VanKrevelen, D. W. 1984. Organic geochemistry - Old and new. Organic Geochemistry. 6, 1-10

[35]. Vine, J. D., and Tourtelot, E. B., 1970. Geochemistry of black shale deposits: A summary report. Economic Geology, v. 65, p. 25272.

[36]. Whiteman, A., 1982. Nigeria: Its petroleum geology resources and potentials, Vol. 2, Graham and Trotman Publication, London SWIVIDE. 